\title{
Fishing top predators indirectly affects condition and reproduction in a reef-fish community
}

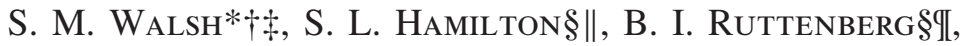 \\ M. K. Donovan** and S. A. Sandint†
}

*The Nature Conservancy, 4245 North Fairfax Dr, Suite 100, Arlington, VA 22203-1606, U.S.A., †Environmental Change Initiative, Brown University, Box 1951, Providence, RI 02912, U.S.A., §Marine Science Institute, University of California, Santa Barbara, CA 91306-6150, U.S.A., ||Moss Landing Marine Laboratories, 8272 Moss Landing Road, Moss Landing, CA 95039, U.S.A., IINational Marine Fisheries Service, Southeast Fisheries Science Center, 75 Virginia Beach Drive, Miami, FL 33149, U.S.A., **Department of Zoology,

University of Hawaii, 2538 McCarthy Mall, Edmondson 165, Honolulu, HI 96822, U.S.A. and $\dagger+$ Scripps Institution of Oceanography, 9500 Gilman Drive, La Jolla, CA 92083-0202, U.S.A.

(Received 5 August 2011, Accepted 8 November 2011)

\begin{abstract}
To examine the indirect effects of fishing on energy allocation in non-target prey species, condition and reproductive potential were measured for five representative species (two-spot red snapper Lutjanus bohar, arc-eye hawkfish Paracirrhites arcatus, blackbar devil Plectroglyphidodon dickii, bicolour chromis Chromis margaritifer and whitecheek surgeonfish Acanthurus nigricans) from three reef-fish communities with different levels of fishing and predator abundance in the northern Line Islands, central Pacific Ocean. Predator abundance differed by five to seven-fold among islands, and despite no clear differences in prey abundance, differences in prey condition and reproductive potential among islands were found. Body condition (mean body mass adjusted for length) was consistently lower at sites with higher predator abundance for three of the four prey species. Mean liver mass (adjusted for total body mass), an indicator of energy reserves, was also lower at sites with higher predator abundance for three of the prey species and the predator. Trends in reproductive potential were less clear. Mean gonad mass (adjusted for total body mass) was high where predator abundance was high for only one of the three species in which it was measured. Evidence of consistently low prey body condition and energy reserves in a diverse suite of species at reefs with high predator abundance suggests that fishing may indirectly affect non-target prey-fish populations through changes in predation and predation risk.

(C) 2012 The Authors
\end{abstract} Journal of Fish Biology (c) 2012 The Fisheries Society of the British Isles

Key words: energy allocation; gonad; Line Islands; liver; predation risk; prey.

\section{INTRODUCTION}

Ecosystem-based fisheries management requires a better understanding of the indirect effects of fishing on non-target species, but these effects have been more difficult to measure than direct effects on target species (Heithaus et al., 2008). One of the most 
well-documented effects of fishing is the dramatic decline in top predators, the primary target of many fisheries (Jackson et al., 2001; Myers \& Worm, 2003; Pandolfi et al., 2003; Newman et al., 2006; Stevenson et al., 2007; DeMartini et al., 2008; Sandin et al., 2008; Walsh, 2011). Ecological theory predicts that a decline in predators should reduce predation and result in an increase in prey populations. Instances of prey release are common in systems with strong species interactions or invertebrate prey species, such as sea urchins or sea stars (McClanahan \& Muthiga, 1988; Dulvy et al., 2004; Borer et al., 2005; Myers et al., 2007; Terborgh \& Estes, 2010). These examples are, however, rare in coral-reef ecosystems characterized by complex food webs (Sandin et al., 2010). Although fishing top predators may not have clear effects on prey abundance in these systems, the removal of predators may still have important indirect effects on energy allocation in prey fishes (Heithaus et al., 2008).

Fishing predators may indirectly increase prey-fish body condition, energy reserves and reproductive potential by reducing predator abundance and associated predation rates and predation risk. When predators are scarce, prey do not need to allocate as much energy to functions that increase survivorship and instead can direct this energy to growth, storage and reproduction (Lima, 1986; Wingfield et al., 1998). Prey can spend less time avoiding predators and can forage more often and over larger areas (Skelly \& Werner, 1990; Schmitz et al., 1997; Madin et al., 2010; Jones \& Dornhaus, 2011). As a result, prey may be able to consume more food or seek out higher quality food (Werner et al., 1983; Longland, 1991; Diehl \& Eklöv, 1995; Morrison, 1999; Jones \& Dornhaus, 2011). In addition, prey exposed to lower predation risk have lower mass-specific metabolic rates meaning that less energy is required for maintenance (Woodley \& Peterson, 2003; Sunardi et al., 2007; Slos \& Stoks, 2008; Hawlena \& Schmitz, 2010). Behavioural or physiological changes in prey under low predator conditions may result in higher net energy intake, which may translate into greater mass gain or storage of energy in fat reserves (Skelly \& Werner, 1990; Hik, 1995; Boonstra et al., 1998; Karels et al., 2000; Garvey et al., 2004; Pérez-Tris et al., 2004). Higher body condition and energy reserves may lead to higher fecundity in females or competitive ability in males (Peckarsky et al., 1993; Scrimgeour \& Culp, 1994; Godin, 1995; Boonstra et al., 1998; Kotiaho et al., 1998; Karels et al., 2000). For instance, females that are in good condition may make proportionally larger investments in reproduction without greatly increasing their risk of mortality (Lambert \& Dutil, 2000). Females in poor condition may also, however, make large investments in reproduction even when mortality risk is high if strategies to increase survivorship and future reproduction would have limited benefits (Levins, 1968; Reznick \& Endler, 1982; Sibley \& Calow, 1986; Stearns, 1992).

The status of fish populations has been assessed using measures of condition and reproduction, often attributing higher condition, energy reserves and reproductive potential to lower temperatures and higher food availability (Lambert \& Dutil, 1997; Froese, 2006). A growing number of studies show, however, that fishing may also affect condition and reproduction of target species. For instance, fishing may exacerbate the negative effect of poor environmental conditions on condition, energy reserves and reproductive potential (Lambert \& Dutil, 1997, 2000; Ballón et al., 2002), alter condition and fecundity in size-specific ways (Ballón et al., 2002; Rijnsdorp et al., 2010) or reduce the size or age at maturity or sex change (Armsworth, 2001; Hawkins \& Roberts, 2003; Olsen et al., 2004; Hamilton et al., 2007). Although effects of environmental conditions and predation on condition and 
reproduction in non-target species have been well studied (especially for larval or juvenile stages) (Montgomery \& Galzin, 1993; McCormick \& Molony, 1995; Garvey et al., 2004; Hoey \& McCormick, 2004; Pratchett et al., 2004; Berumen et al., 2005), it remains unclear how or if fishing indirectly affects condition and reproduction in non-target species through changes in predator abundance. One of the challenges in understanding this effect is that there are few places to make appropriate comparisons between fish communities where the primary difference is the fishing of predators (Heithaus et al., 2008).

This study used spatial comparisons of condition and reproduction of fishes from reefs in Palmyra Atoll, south-eastern Kiritimati Atoll and north-western Kiritimati Atoll in the northern Line Islands, central Pacific Ocean, to examine the indirect effects of fishing predators on prey energy allocation. Previous studies on these reefs found that predator abundance is higher in unfished Palmyra and lightly fished southeastern Kiritimati than in north-western Kiritimati (Stevenson et al., 2007; DeMartini et al., 2008; Sandin et al., 2008; Walsh, 2011). These studies found, however, that fishing was not associated with a consistent pattern in biomass for any of the major prey trophic groups (DeMartini et al., 2008; Sandin et al., 2008; Ruttenberg et al., 2011; Walsh, 2011). Studies comparing other metrics of prey fishes at Palmyra and north-western Kiritimati found that higher predator abundance was associated with smaller mean sizes and ages of prey fishes (Ruttenberg et al., 2011), smaller sizes at sex change for protogynous parrotfishes (DeMartini et al., 2008) and reduced prey foraging time and areas (Madin et al., 2010). Building on these previous studies, this study investigated the hypothesis that body condition, energy reserves and reproductive potential may be higher for fishes under low predator conditions in fished north-western Kiritimati than for fishes under high predator conditions in lightly fished south-eastern Kiritimati and unfished Palmyra. To test this hypothesis, the body, liver and gonad mass of five representative fish species (one predator and four prey species) from reefs in the north-western and south-eastern regions of Kiritimati and in Palmyra were compared.

\section{MATERIALS AND METHODS}

\section{STUDY SITES}

Palmyra and Kiritimati Atolls in the northern Line Islands, central Pacific Ocean, provide a unique opportunity to test the indirect effects of fishing on prey energy allocation (Fig. 1) (Knowlton \& Jackson, 2008; Sandin et al., 2008). These atolls have similar species assemblages and environmental conditions because of their close proximity $(c .700 \mathrm{~km})$, but they have very different predator populations due to fishing (Fig. 1 and Table I) (Sandin et al., 2008). The fringing reefs of both islands are bathed by oligotrophic waters; however, Kiritimati has somewhat higher chlorophyll $a$ concentrations and cooler waters due to regional upwelling around the equator and localized upwelling on the north-western side of the island (Table I) (Sandin et al., 2008; Walsh, 2011). Palmyra has been protected from fishing by the U.S. Fish and Wildlife Service as a National Wildlife Refuge (and became part of the Pacific Remote Islands National Monument in 2009) (Federal Register, 2001; Kempthorne, 2009). Kiritimati is part of the Republic of Kiribati and has at least 5000 inhabitants (Kiribati Statistics Office, 2005). The effect of fishing on Kiritimati began relatively recently because, historically, Kiritimati had no permanent population (Sandin et al., 2008). A permanent population was established for copra production (coconut agriculture) and has grown dramatically in recent decades following a population re-settlement programme that brought people from 

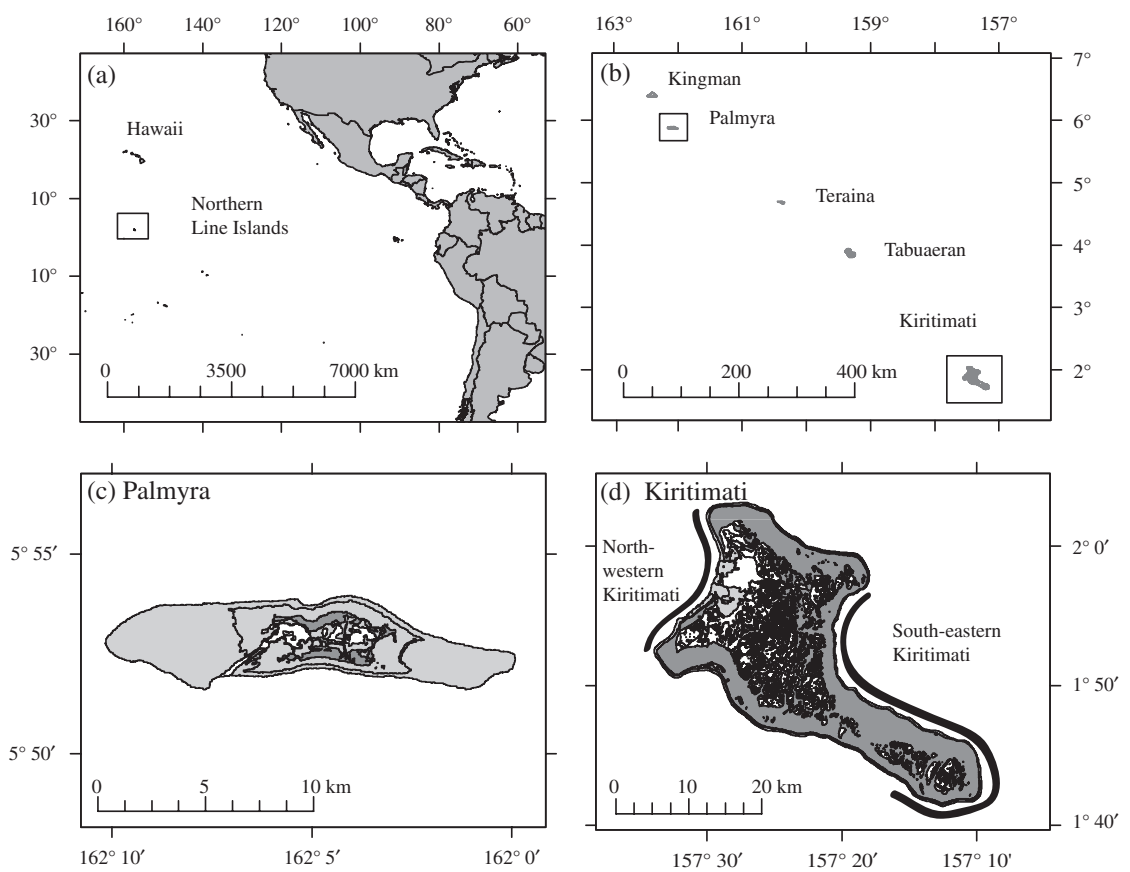

FIG. 1. Maps of the study regions in the (a and b) northern Line Islands: (c) Palmyra and (d) north-western Kiritimati and south-eastern Kiritimati $(\square$, reef; $\square$, land; $\square$, lagoon; $\rightarrow$, subregion).

Tarawa, the capital of the Republic of Kiribati (c. $3000 \mathrm{~km}$ to the west) (Sandin et al., 2008; Walsh, 2011).

Fishing in Kiritimati is concentrated on the leeward or north-western side of the island near the largest villages, while the windward or south-eastern coast experiences little fishing pressure because of its exposure to persistent easterly trade winds and remoteness (there are very few boats or cars in Kiritimati) (Table I) (Walsh, 2011). As a consequence, fish communities in the south-eastern side of Kiritimati more closely resemble fish communities in the protected Palmyra Atoll than fish communities in the north-western side of Kiritimati (Sandin et al., 2008; Walsh, 2011). Fishing in Kiritimati has primarily affected top predators with little affect on prey fishes (except for fishing for the aquarium trade), because of the recent nature of fishing and the fact that about half of fishing trips use hook and line, which targets large predators (Table I) (Walsh, 2011). Previous studies have shown that predator biomass in Palmyra and south-eastern Kiritimati is five to seven times greater than in northwestern Kiritimati and dominated by snappers, jacks, groupers and, in the case of Palmyra, sharks (DeMartini et al., 2008; Sandin et al., 2008; Walsh, 2011). Notably, sharks are far less abundant in south-eastern Kiritimati probably due to shark finning (Walsh, 2011). None of the major prey-fish trophic groups, however, show a pattern consistent with prey release due to fishing predators (DeMartini et al., 2008; Sandin et al., 2008; Walsh, 2011). Fished reefs at north-western Kiritimati also have higher algal cover (turf and macroalgae) and lower coral cover compared to lightly and unfished south-eastern Kiritimati and Palmyra, respectively (Table I) (Sandin et al., 2008; Walsh, 2011).

\section{STUDY SPECIES}

The five study species represent the five major trophic groups (predators, benthic invertivores, omnivores, planktivores and herbivores) and were among the most abundant species in these trophic groups on previous surveys of both atolls (DeMartini et al., 2008; Sandin 
TABLE I. Mean \pm S.D. of ecosystem and environmental attributes in the three study regions: north-western Kiritimati (KirNW), south-eastern Kiritimati (KirSE) and Palmyra (Pal) (all data except oceanographic data derived from DeMartini et al., 2008; Sandin et al., 2008; Walsh, 2011; Ruttenberg et al., 2011)

\begin{tabular}{|c|c|c|c|}
\hline Factor & KirNW & KirSE & Pal \\
\hline $\begin{array}{l}\text { Fish catch }\left(\mathrm{kg} \mathrm{km}^{-1} \text { week }^{-1}\right) \\
\text { Predation pressure }\end{array}$ & $173 \cdot 88 \pm 34 \cdot 87$ & $43 \cdot 62 \pm 15 \cdot 80$ & 0.00 \\
\hline Predator density (number $\mathrm{m}^{-2}$ ) & $0 \cdot 31 \pm 0.04$ & $0.19 \pm 0.05$ & $0 \cdot 13 \pm 0.01$ \\
\hline $\begin{array}{l}\text { Predator density }\left(\mathrm{g} \mathrm{m}^{-2}\right) \\
\text { Benthic cover }\end{array}$ & $24 \cdot 76 \pm 5 \cdot 05$ & $124 \cdot 36 \pm 34 \cdot 70$ & $168 \cdot 43 \pm 24 \cdot 12$ \\
\hline Coral co & $14.99 \pm 2.26$ & $38.42 \pm 4.04$ & $20 \cdot 36 \pm 2 \cdot 67$ \\
\hline Turf al & $52 \cdot 59 \pm 4$ & $13 \cdot 37$ & $24.95 \pm$ \\
\hline Macroalgal & $16 \cdot 21 \pm 3$ & $5 \cdot 82 \pm 0.94$ & $17 \cdot 77 \pm 2 \cdot 19$ \\
\hline Fish & & & \\
\hline Lutjanus bohar (numb & 0.02 & 0.03 & $0.04 \pm$ \\
\hline Paracirrhites arcatus (number $\mathrm{m}^{-2}$ ) & $0.03 \pm 0.00$ & $0.05 \pm 0.01$ & $0.08 \pm 0.01$ \\
\hline Chromis margaritifer (number $\mathrm{m}^{-2}$ ) & $1.53 \pm 0.26$ & $0.59 \pm 0.14$ & $0.51 \pm 0.08$ \\
\hline Plectroglyphidodon dickii (number $\mathrm{m}^{-2}$ ) & $0 \cdot 07 \pm 0.01$ & $0.27 \pm 0.04$ & $0.03 \pm 0.01$ \\
\hline $\begin{array}{l}\text { Acanthurus nigricans (number } \mathrm{m}^{-2} \text { ) } \\
\text { Oceanography* }\end{array}$ & $0.02 \pm 0.00$ & $0.05 \pm 0.01$ & $0.07 \pm 0.01$ \\
\hline$\left(\mathrm{mg} \mathrm{m}^{-3}\right)$ & 10 & 0.117 & $0.11 \pm 0.02$ \\
\hline Temperature $\left({ }^{\circ} \mathrm{C}\right)$ & $28.22 \pm 0.49$ & $28 \cdot 03 \pm 0.17$ & $28.73 \pm 0.14$ \\
\hline
\end{tabular}

*Average of monthly values (July 2002 to June 2007) from MODIS on Aqua (Acker \& Leptoukh, 2007).

et al., 2008; Walsh, 2011). The two-spot red snapper Lutjanus bohar (Forsskål 1775) [maximum total length $\left(L_{\mathrm{T}}\right): 90 \mathrm{~cm}$ ] mainly feeds on fishes, is preyed on by reef sharks and is a target of the local fishery (Frimodt, 1995; Walsh, 2011). The arc-eye hawkfish Paracirrhites arcatus (Cuvier 1829) (maximum $L_{\mathrm{T}}: 20 \mathrm{~cm}$ ) is typically associated with small branching corals, feeds on shrimp, crabs and other crustaceans and is prey for smaller groupers such as the peacock hind Cephalopholis argus Schneider 1801 (Hiatt \& Strasburg, 1960; Randall \& Brock, 1960; Lieske \& Myers, 1994; Myers, 1999). The bicolour chromis Chromis margaritifer Fowler 1946 (maximum $L_{\mathrm{T}}: 9 \mathrm{~cm}$ ) is a shoaling species that shelters in branching corals and reef crevices, but feeds on zooplankton in the water column (Lieske \& Myers, 1994). Chromis margaritifer is a prey for many reef predators because of its small size and abundance (Hiatt \& Strasburg, 1960). The blackbar devil Plectroglyphidodon dickii (Liénard 1839) (maximum $L_{\mathrm{T}}: 11 \mathrm{~cm}$ ) establishes territories on Acropora spp. corals and feeds primarily on filamentous algae and small benthic invertebrates (Allen, 1986; Myers, 1991). The yellow-edged moray eel Gymnothorax flavimarginatus (Rüppell 1830) is a known predator of P. dickii (Hiatt \& Strasburg, 1960). The whitecheek surgeonfish Acanthurus nigricans L. 1758 (maximum $L_{\mathrm{T}}: 21 \mathrm{~cm}$ ) feeds on filamentous algae (Randall et al., 1990; Choat et al., 2004). Notably, only one of these species, L. bohar, is targeted by the fishers of Kiritimati. Fishers also target the known predators of the four prey species included in this study (e.g. groupers, reef sharks, eels and various piscivores).

\section{COLLECTIONS}

Collections of 19-109 individuals of each species were made using nets, spears and hookand-line gear from reefs that experience no fishing or low fishing in Palmyra and south-eastern Kiritimati and from reefs that experience high levels of fishing in north-western Kiritimati. Collections from Palmyra and north-western Kiritimati were made during August 2006, while collections from south-eastern Kiritimati were made during August 2007. Each individual's 
total body mass $\left(M_{\mathrm{T}}\right)$ and $L_{\mathrm{T}}$ were recorded prior to dissection. The liver $\left(M_{\mathrm{L}}\right)$ and gonad $\left(M_{\mathrm{G}}\right)$ mass were recorded and the sex was determined by gross examination of the gonad. The $M_{\mathrm{T}}$, adjusted for $L_{\mathrm{T}}$, and $M_{\mathrm{L}}$, adjusted for $M_{\mathrm{T}}$, using standard regression methods were used as indicators of condition and energy reserves, respectively (Lambert \& Dutil, 1997). The $M_{\mathrm{G}}$ (of mature females only), adjusted for $M_{\mathrm{T}}$ using standard regression methods, was used as an indicator of reproductive potential (Lloret \& Planes, 2003).

\section{STATISTICAL ANALYSES}

To compare indicators between regions, ordinary least-squares regression was used to estimate the relationship between $M_{\mathrm{T}}$ and standard length $\left(L_{\mathrm{S}}\right)\left(\ln \left(M_{\mathrm{T}}\right)=\alpha_{0}+\alpha_{1} \ln \left(L_{\mathrm{S}}\right)\right)$, $M_{\mathrm{L}}$ and $M_{\mathrm{T}}\left(\ln \left(M_{\mathrm{L}}\right)=\beta_{0}+\beta_{1} M_{\mathrm{T}}\right)$ and $M_{\mathrm{G}}$ and $M_{\mathrm{T}}\left(\ln \left(M_{\mathrm{G}}\right)=\gamma_{0}+\gamma_{1} M_{\mathrm{T}}\right)$, where $\alpha, \beta$ and $\gamma$ are coefficients. The region was included as a categorical variable that could affect the slope, intercept or both, which represented differences in the rate of somatic growth, initial size or both $\left(\right.$ e.g. $\ln \left(M_{\mathrm{T}}\right)=\alpha_{0}+\alpha_{1} x+\alpha_{2} z+\alpha_{3} x \ln \left(L_{\mathrm{S}}\right)+\alpha_{4} z \ln \left(L_{\mathrm{S}}\right)$, where $x$ is south-eastern Kiritimati and $z$ is Palmyra) (see Tables SI-SIII, Supporting information, for all model specifications). North-western Kiritimati was the reference region and, therefore, was not included explicitly as a variable in the models. The best fit model was chosen using the Akaike information criterion (AIC) corrected for small sample sizes (Hurvich \& Tsai, 1989; Burnham \& Anderson, 2002) (Tables SI-SIII, Supporting information). These models were used to calculate adjusted means of the dependent variables [body mass $\left(\bar{M}_{\mathrm{T}}^{\prime}\right)$, liver mass $\left(\bar{M}_{\mathrm{L}}^{\prime}\right)$ and gonad mass $\left.\left(\bar{M}_{\mathrm{G}}^{\prime}\right)\right]$, which were then tested for differences between pairs of regions using $t$-tests with Holm's sequential Bonferroni correction (Holm, 1979).

\section{RESULTS}

Model selection procedures showed that differences in adjusted $\bar{M}_{\mathrm{T}}^{\prime}, \bar{M}_{\mathrm{L}}^{\prime}$ and $\bar{M}_{\mathrm{G}}^{\prime}$ may be due to both allometric (differences in slope) and isometric (differences in intercept) differences across regions (Tables SI-SIII, Supporting information). In most cases, more than one of the nine candidate models considered had a similar likelihood $\left(\triangle \mathrm{AIC}_{\mathrm{c}}<2\right)$ of being the best model to represent the $M_{\mathrm{T}}, M_{\mathrm{L}}$ or $M_{\mathrm{G}}$ data for each species (Tables SI-SIII, Supporting information). With few exceptions, models with a $\Delta \mathrm{AIC}_{\mathrm{c}}<2$ resulted in the same qualitative trends in $\bar{M}_{\mathrm{T}}^{\prime}, \bar{M}_{\mathrm{L}}^{\prime}$ and $\bar{M}_{\mathrm{G}}^{\prime}$ across the regions. Consequently, only the estimation results and adjusted means from the models with the lowest $\mathrm{AIC}_{\mathrm{c}}$ were presented (Tables II and III and Figs 2-4). The best models of $M_{\mathrm{T}}$ were highly significant $(P<0.001)$ and explained between 89 and $99 \%$ of the variance in $M_{\mathrm{T}}$ for all species (Table II). The best models of $M_{\mathrm{L}}$ were also highly significant $(P<0.001)$ but explained less of the variance in $M_{\mathrm{L}}(35-83 \%)$ (Table II). Far less of the variance in $M_{\mathrm{G}}(21-47 \%)$ was explained by the best models but these models were still highly significant $(P<0 \cdot 01)$ (Table II).

The $\bar{M}_{\mathrm{T}}^{\prime}$ for the predator, L. bohar, did not differ between regions with high fishing (north-western Kiritimati) and no fishing (Palmyra) [Fig. 2(a) and Table II]. No samples were available from south-eastern Kiritimati to make comparisons. In contrast, $\bar{M}_{\mathrm{T}}^{\prime}$ for three of the prey species was consistently lower in regions with low fishing and high predator abundance. The $\bar{M}_{\mathrm{T}}^{\prime}$ of P. arcatus, $P$. dickii and A. nigricans was lower in Palmyra, intermediate in south-eastern Kiritimati and highest at northwestern Kiritimati [Fig. 2(b), (c), (e) and Table II]. The best model of $M_{\mathrm{T}}$ for the prey species, $C$. margaritifer, showed no differences in $\bar{M}_{\mathrm{T}}^{\prime}$ among these three regions [Fig. 2(d) and Table II]; however, four of the five models with a $\Delta \mathrm{AIC}_{\mathrm{c}}<2$ 
TABLE II. Estimates of mean \pm s.E. body mass $\left(M_{\mathrm{T}}\right)$, liver mass $\left(M_{\mathrm{L}}\right)$ and gonad mass $\left(M_{\mathrm{G}}\right)$ from best models (Tables SI-SIII, Supporting information). Dependent variables are ln transformed (except for $M_{\mathrm{L}}$ for Acanthurus nigricans). The predictor variables are the regions: south-eastern Kiritimati $(x)$ and Palmyra $(z)$. The reference region is north-western Kiritimati. The covariate $(\mathrm{CV} ; y)$ for models of $M_{\mathrm{T}}$ is ln of standard length $\left(L_{\mathrm{S}}\right)$ and for models of $M_{\mathrm{L}}$ and $M_{\mathrm{G}}$ is $M_{\mathrm{T}}$

\begin{tabular}{|c|c|c|c|c|}
\hline Species & Variable & $M_{\mathrm{T}}$ & $M_{\mathrm{L}}$ & $M_{\mathrm{G}}$ \\
\hline \multirow[t]{8}{*}{ Lutjanus bohar } & $y$ & $2.90 \pm 0.03 * * *$ & $0.00 \pm 0.00 * * *$ & - \\
\hline & $z$ & $0.01 \pm 0.03$ & $-0.93 \pm 0.24 * * *$ & - \\
\hline & $x$ & - & - & - \\
\hline & $y \times z$ & $0.00 \pm 0.00 * * *$ & - & - \\
\hline & $y \times x$ & - & - & - \\
\hline & Constant & - & $3 \cdot 31 \pm 0.10^{* * *}$ & - \\
\hline & $n$ & 114 & 69 & - \\
\hline & $r^{2}$ & 0.99 & $0 \cdot 84$ & - \\
\hline \multirow[t]{8}{*}{ Paracirrhites arcatus } & $y$ & $2 \cdot 64 \pm 0.16^{* * *}$ & $0.03 \pm 0.01 * *$ & $0 \cdot 06 \pm 0.04$ \\
\hline & $z$ & $-0.40 \pm 0.25$ & $0 \cdot 60 \pm 0 \cdot 10^{* * * *}$ & - \\
\hline & $x$ & $-0.58 \pm 0.26^{*}$ & $0.37 \pm 0.23$ & $0.45 \pm 0.12 * * *$ \\
\hline & $y \times z$ & $0.27 \pm 0.13 *$ & - & $0.05 \pm 0.02 *$ \\
\hline & $y \times x$ & $0.32 \pm 0.13^{*}$ & $0 \cdot 02 \pm 0 \cdot 01$ & - \\
\hline & Constant & $-2.86 \pm 0.31^{* * *}$ & $-3.94 \pm 0.21 * * *$ & $-3.04 \pm 0.35^{* * *}$ \\
\hline & $n$ & 221 & 182 & 55 \\
\hline & $r^{2}$ & 0.95 & 0.43 & 0.34 \\
\hline \multirow{8}{*}{$\begin{array}{l}\text { Plectroglyphidodon } \\
\quad \text { dickii }\end{array}$} & $y$ & $2 \cdot 96 \pm 0 \cdot 11^{* * *}$ & $0.06 \pm 0.03^{*}$ & $0.11 \pm 0.05^{*}$ \\
\hline & $z$ & - & - & $0.09 \pm 0.21$ \\
\hline & $x$ & $0.50 \pm 0.25$ & $0.13 \pm 0.12$ & $-0.30 \pm 0.18$ \\
\hline & $y \times z$ & $0.07 \pm 0.01 * * *$ & $0.07 \pm 0.02 * *$ & - \\
\hline & $y \times x$ & $-0.25 \pm 0.16$ & - & - \\
\hline & Constant & $-3.05 \pm 0.20^{* * *}$ & $-4 \cdot 16 \pm 0.22 * * *$ & $-3 \cdot 30 \pm 0.41 * * *$ \\
\hline & $n$ & 191 & 122 & 59 \\
\hline & $r^{2}$ & 0.89 & $0 \cdot 35$ & 0.21 \\
\hline \multirow{8}{*}{ Chromis margaritifer } & $y$ & $3.71 \pm 0.38 * * *$ & $-0.13 \pm 0.10$ & - \\
\hline & $z$ & $0.46 \pm 0.26$ & $0.65 \pm 0.17 * * *$ & - \\
\hline & $x$ & $1.22 \pm 0.58^{*}$ & $-1.19 \pm 0.68$ & - \\
\hline & $y \times z$ & $-0.28 \pm 0.18$ & - & - \\
\hline & $y \times x$ & $-0.80 \pm 0.36^{*}$ & $0.29 \pm 0.11^{*}$ & - \\
\hline & Constant & $-4.27 \pm 0.61^{* * *}$ & $-3.48 \pm 0.67 * * *$ & - \\
\hline & $n$ & 139 & 41 & - \\
\hline & $r^{2}$ & 0.93 & $0 \cdot 41$ & - \\
\hline \multirow[t]{8}{*}{ Acanthurus nigricans } & $y$ & $2.84 \pm 0.04 * * *$ & $0.01 \pm 0.00 * * *$ & $0.01 \pm 0.01$ \\
\hline & $z$ & $0.14 \pm 0.02 * * *$ & $0.05 \pm 0.07$ & $-4.02 \pm 1.53 *$ \\
\hline & $x$ & - & $0.08 \pm 0.06$ & $-0.46 \pm 0.22 *$ \\
\hline & $y \times z$ & - & - & $0.02 \pm 0.01$ \\
\hline & $y \times x$ & $0.01 \pm 0.01 *$ & - & - \\
\hline & Constant & $-2.78 \pm 0.11^{* * *}$ & $-0 \cdot 29 \pm 0 \cdot 10^{* *}$ & $-0.64 \pm 1.39$ \\
\hline & $n$ & 238 & 191 & 83 \\
\hline & $r^{2}$ & 0.95 & 0.71 & $0 \cdot 47$ \\
\hline
\end{tabular}

$n$, sample size; $* P<0.05 ; * * P<0.01 ; * * * P<0.001$.

for C. margaritifer showed that $\bar{M}_{\mathrm{T}}^{\prime}$ was higher in south-eastern Kiritimati than in Palmyra.

Despite a lack of differences in $\bar{M}_{\mathrm{T}}^{\prime}$ for L. bohar, $\bar{M}_{\mathrm{L}}^{\prime}$ was lower where there was no fishing (Palmyra) than where fishing was highest (north-western Kiritimati) 
TABLE III. Paired comparisons of adjusted mean body mass $\left(\bar{M}_{\mathrm{T}}^{\prime}\right)$, liver mass $\left(\bar{M}_{\mathrm{L}}^{\prime}\right)$ and gonad mass $\left(\bar{M}_{\mathrm{G}}^{\prime}\right)$ among regions with high fishing (north-western Kiritimati, KirNW), low fishing (south-eastern Kiritimati, KirSE) and no fishing (Palmyra, Pal). Note that no collections of Lutjanus bohar were made on KirSE. Using Holm's sequential Bonferroni correction, differences were considered significant at $P$ values of $<0.05,<0.025$ and $<0.017$ for the three comparisons ordered from lowest to highest $t$ statistic

\begin{tabular}{|c|c|c|c|c|c|c|c|c|c|}
\hline \multirow[b]{2}{*}{ Comparison } & \multicolumn{3}{|c|}{$\bar{M}_{\mathrm{T}}^{\prime}$} & \multicolumn{3}{|c|}{$\bar{M}_{\mathrm{L}}^{\prime}$} & \multicolumn{3}{|c|}{$\bar{M}_{\mathrm{L}}^{\prime}$} \\
\hline & $t$ & d.f. & $P$ & $t$ & d.f. & $P$ & $t$ & d.f. & $P$ \\
\hline \multicolumn{10}{|l|}{ Lutjanus bohar } \\
\hline KirNW $v$. Pal & 0.54 & 112 & $>0.05$ & 2.76 & 67 & $<0 \cdot 01$ & NA & & \\
\hline KirNW $v$. KirSE & NA & & & NA & & & NA & & \\
\hline KirSE $v$. Pal & NA & & & NA & & & NA & & \\
\hline \multicolumn{10}{|c|}{ Paracirrhites arcatus } \\
\hline KirNW $v . \mathrm{Pal}$ & $6 \cdot 20$ & 110 & $<0.001$ & $5 \cdot 81$ & 83 & $<0.001$ & $2 \cdot 02$ & 24 & $<0 \cdot 05$ \\
\hline KirNW $v$. KirSE & $2 \cdot 49$ & 178 & $<0.01$ & $8 \cdot 55$ & 145 & $<0 \cdot 001$ & $2 \cdot 41$ & 44 & $<0.05$ \\
\hline KirSE $v . \mathrm{Pal}$ & $3 \cdot 67$ & 148 & $<0 \cdot 001$ & $1 \cdot 11$ & 130 & $>0 \cdot 05$ & $0 \cdot 61$ & 36 & $>0 \cdot 05$ \\
\hline \multicolumn{10}{|c|}{ Plectroglyphidodon dickii } \\
\hline KirNW $v$. Pal & $6 \cdot 54$ & 104 & $<0.001$ & 3.73 & 68 & $<0.001$ & 0.43 & 28 & $>0 \cdot 05$ \\
\hline KirNW $v$. KirSE & $5 \cdot 25$ & 147 & $<0 \cdot 001$ & 1.06 & 87 & $>0.05$ & $1 \cdot 72$ & 44 & $>0 \cdot 05$ \\
\hline KirSE $v . \mathrm{Pal}$ & $2 \cdot 40$ & 125 & $<0 \cdot 05$ & $2 \cdot 85$ & 83 & $<0.01$ & $2 \cdot 06$ & 40 & $<0 \cdot 05$ \\
\hline \multicolumn{10}{|c|}{ Chromis margaritifer } \\
\hline KirNW $v$. Pal & $2 \cdot 37$ & 112 & $<0 \cdot 05$ & 3.91 & 26 & $<0 \cdot 001$ & NA & & \\
\hline KirNW $v$. KirSE & 1.92 & 99 & $>0.05$ & 0.21 & 23 & $>0.05$ & NA & & \\
\hline KirSE $v . \mathrm{Pal}$ & $0 \cdot 65$ & 62 & $>0.05$ & $2 \cdot 60$ & 27 & $<0.01$ & NA & & \\
\hline \multicolumn{10}{|c|}{ Acanthurus nigricans } \\
\hline KirNW $v$. Pal & $6 \cdot 63$ & 128 & $<0 \cdot 001$ & 0.66 & 88 & $0 \cdot 51$ & 4.93 & 42 & $<0.001$ \\
\hline KirNW $v$. KirSE & $2 \cdot 19$ & 186 & $<0.05$ & $1 \cdot 24$ & 143 & $>0.05$ & $1 \cdot 30$ & 53 & $>0.05$ \\
\hline KirSE $v$. Pal & $5 \cdot 12$ & 156 & $<0 \cdot 001$ & 0.49 & 145 & $>0.05$ & $4 \cdot 30$ & 65 & $<0.001$ \\
\hline
\end{tabular}

NA, not available.

[Fig. 3(a) and Table II]. Three of the four prey species (P. arcatus, P. dickii and C. margaritifer) had lower $\bar{M}_{\mathrm{L}}^{\prime}$ where there was no fishing (Palmyra) as compared to reefs where fishing was highest (north-western Kiritimati) [Fig. 3(b)-(e) and Table II]. The $M_{\mathrm{L}}$ of these three species under intermediate fishing conditions (south-eastern Kiritimati) was not, however, distinguishable from $M_{\mathrm{L}}$ in one of the other regions (Palmyra or north-western Kiritimati) [Fig. 3(b)-(e) and Table II]. Both $P$. dickii and $C$. margaritifer had lower $\bar{M}_{\mathrm{L}}^{\prime}$ at Palmyra than at north-western Kiritimati and south-eastern Kiritimati, but $\bar{M}_{\mathrm{L}}^{\prime}$ in north-western Kiritimati and southeastern Kiritimati were indistinguishable [Fig. 3(c), (d) and Table II]. In contrast, $P$. arcatus had lower $\bar{M}_{\mathrm{L}}^{\prime}$ in Palmyra and south-eastern Kiritimati than in northwestern Kiritimati, but $\bar{M}_{\mathrm{L}}^{\prime}$ in south-eastern Kiritimati and Palmyra were indistinguishable [Fig. 3(b) and Table II]. Acanthurus nigricans showed no difference in $\bar{M}_{\mathrm{L}}^{\prime}$ across all three regions [Fig. 3(e) and Table II].

Only three prey species ( $P$. arcatus, $P$. dickii and $A$. nigricans) had sufficient numbers of gravid female fish to compare $M_{\mathrm{G}}$ across regions. The $\bar{M}_{\mathrm{G}}^{\prime}$ was higher for A. nigricans in Palmyra than in north-western Kiritimati or south-eastern Kiritimati 

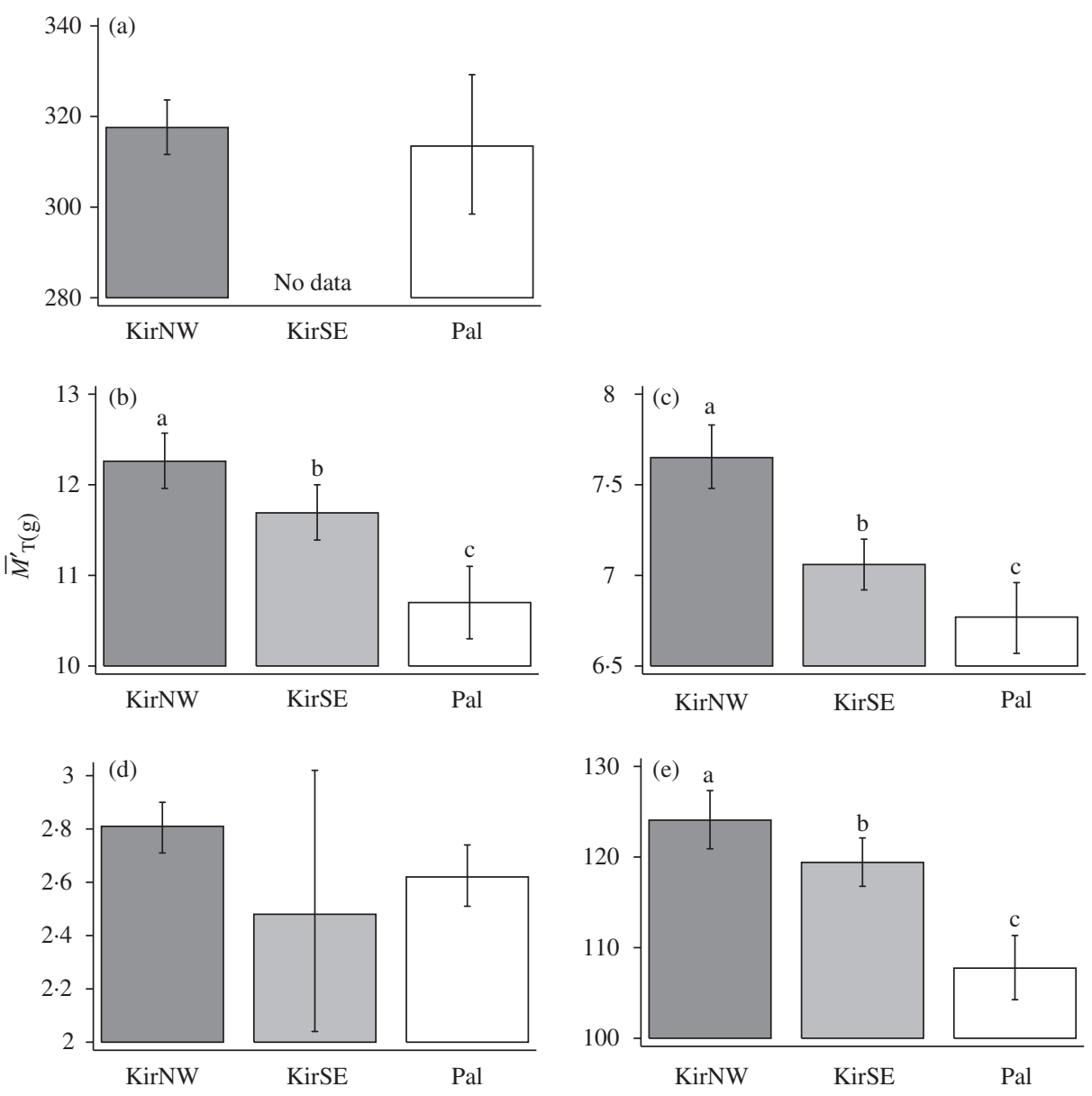

FIG. 2. Adjusted mean total body mass $\left(\bar{M}_{\mathrm{T}}^{\prime}\right)$ and $95 \%$ C.I. by regions [north-western Kiritimati (KirNW), south-eastern Kiritimati (KirSE) and Palmyra (Pal)] from best fit models (Tables II and SI, Supporting information) for: (a) Lutjanus bohar, (b) Paracirrhites arcatus, (c) Plectroglyphidodon dickii, (d) Chromis margaritifer and (e) Acanthurus nigricans. The $\bar{M}_{\mathrm{T}}^{\prime}$ that were determined to be significantly different by a $t$-test with Holm's sequential Bonferroni correction are indicated by lower-case letters (Table III).

[Fig. 4(c) and Table II]. The $\bar{M}_{\mathrm{G}}^{\prime}$ of $P$. dickii and P. arcatus were not different across regions [Fig. 4(a), (b) and Table II]. Although the best model of $M_{\mathrm{G}}$ for $P$. arcatus showed no difference across regions, four of the five models with a $\Delta \mathrm{AIC}_{\mathrm{c}}<2$ showed that $\bar{M}_{\mathrm{G}}^{\prime}$ was greater in north-western Kiritimati than in southeastern Kiritimati.

\section{DISCUSSION}

There is a growing consensus that fishing has ecosystem-wide effects, yet the indirect effects of fishing on non-target species remain unclear (Goñi, 1998; Dayton et al., 

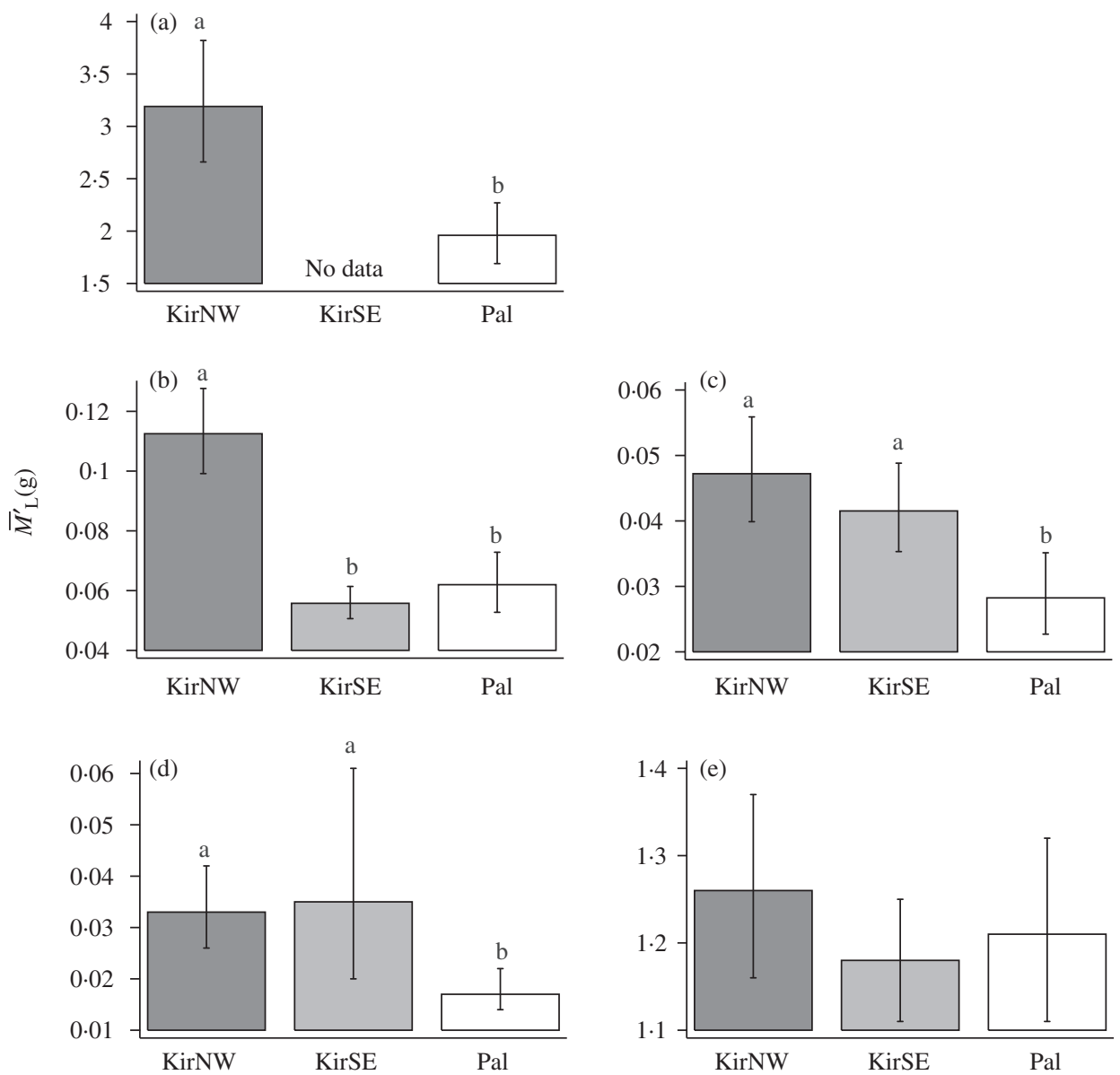

FIG. 3. Adjusted mean liver mass $\left(\bar{M}_{\mathrm{L}}^{\prime}\right)$ and $95 \%$ C.I. by region [north-western Kiritimati (KirNW), southeastern Kiritimati (KirSE) and Palmyra (Pal)] from best fit models (Tables II and SII, Supporting information) for: (a) Lutjanus bohar, (b) Paracirrhites arcatus, (c) Plectroglyphidodon dickii, (d) Chromis margaritifer and (e) Acanthurus nigricans. The $\bar{M}_{\mathrm{L}}^{\prime}$ that were determined to be significantly different by a $t$-test with Holm's sequential Bonferroni correction are indicated by lower-case letter (Table III).

2002; National Research Council, 2006). One of the main ways in which fishing may affect non-target species is by changing predator-prey interactions (Heithaus et al., 2008). Fishing of top predators may lead to an increase in prey populations through prey release (Caddy \& Rodhouse, 1998; Graham et al., 2003; Myers et al., 2007). Prey release is not, however, common in complex systems such as coral reefs (Sandin et al., 2010). Predators may also have important effects on prey that do not involve changes in prey abundance (Lima, 1998), but these effects have not often been considered in the context of fishing (except the studies by DeMartini et al., 2005, 2008; Stallings, 2008; Madin et al., 2010; Ruttenberg et al., 2011). This study tested the effect of fishing predators on prey energy allocation by comparing proxies of condition and reproductive potential in a diverse suite of species from reefs with different levels of fishing in the northern Line Islands. Fishing has resulted in 

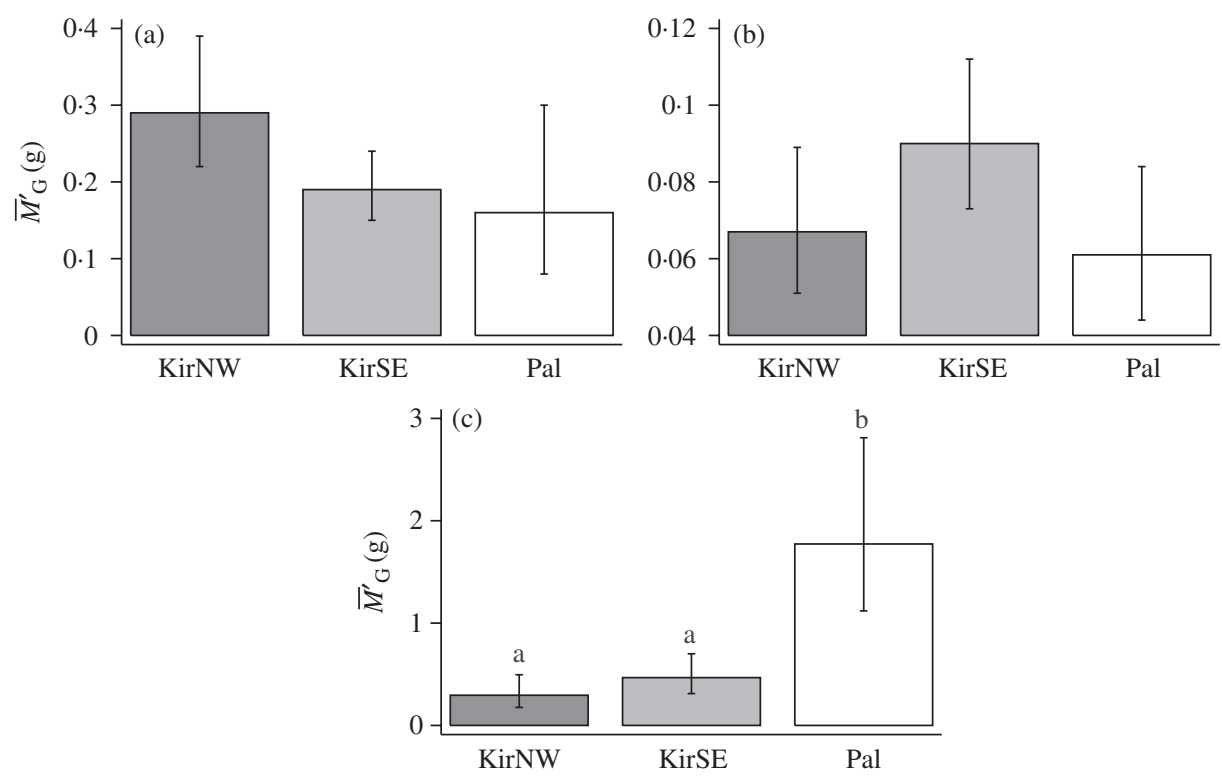

FIG. 4. Adjusted mean gonad mass $\left(\bar{M}_{\mathrm{G}}^{\prime}\right)$ and $95 \%$ C.I. by region [north-western Kiritimati (KirNW), southeastern Kiritimati (KirSE) and Palmyra (Pal)] from best fit models (Tables II and SIII, Supporting information) for: (a) Paracirrhites arcatus, (b) Plectroglyphidodon dickii and (c) Acanthurus nigricans. The $\bar{M}_{\mathrm{G}}^{\prime}$ that were determined to be significantly different by a $t$-test with Holm's sequential Bonferroni correction are indicated by lower-case letters (Table III).

five to seven-fold differences in predator abundance across these reefs (DeMartini et al., 2008; Sandin et al., 2008; Walsh, 2011). Although fishing predators has not been associated with a consistent increase in prey populations in the northern Line Islands (DeMartini et al., 2008; Sandin et al., 2008; Walsh, 2011), this study found that proxies for prey-fish condition were higher when predators were less abundant due to fishing, but that trends in prey-fish reproductive potential were inconsistent.

The differences in prey condition observed in this study may, in part, be the result of changes in predation rates and predation risk due to fishing predators. In a related study, Ruttenberg et al. (2011) found that the prey fishes in this study had reduced size ( $P$. arcatus, C. margaritifer and A. nigricans) and longevity ( $P$. arcatus, $P$. dickii and $A$. nigricans) in Palmyra, where predators are abundant, as compared to northwestern Kiritimati, where fishing has reduced predator abundance. The reduced size and longevity of prey fishes in Palmyra suggest that predation rates may be higher than in north-western Kiritimati, despite no clear pattern in prey abundance. When predation rates are high, prey may allocate less energy to increasing body condition because the benefits, in terms of future reproduction, are low if prey have a high chance of being eaten (Stearns, 1992). In turn, the amount of energy available to improve body condition may be low because the energy required for behaviours that increase survivorship, such as vigilance or predator avoidance, is high (Lima, 1986; Wingfield et al., 1998). Time that prey spend avoiding predators is time that cannot be spent foraging (Sih, 1980; Longland, 1991). Madin et al. (2010) compared the foraging behaviour of three of the species included in this study [P. dickii, A. nigricans 
and $C$. margaritifer; note that $P$. arcatus and L. bohar were not included in the study by Madin et al. (2010)] at Palmyra and north-western Kiritimati and found that prey had reduced foraging areas when background predator abundance was high, predator encounters were high and model predators were introduced. Reduced foraging areas may reduce prey resource consumption and, consequently, body condition (Lima, 1998).

These studies suggest that high predation rates and predation risk may explain the lower body mass and liver mass observed in prey fishes from multiple trophic levels ( $P$. arcatus, $P$. dickii and A. nigricans) on reefs with lower levels of fishing and higher levels of predators in this study. The lack of differences in body mass for the planktivore $C$. margaritifer and the predator L. bohar across reefs may, however, possibly be explained by other factors. Chromis margaritifer showed no evidence of differences in body mass across these reefs despite smaller foraging areas in Palmyra (Madin et al., 2010). One possible explanation is that plankton may not be limiting in Palmyra and south-eastern Kiritimati, despite smaller foraging areas, because of strong currents (Hamman et al., 2004; S. Sandin, pers. obs.). It is also possible that no differences in body mass were detected for these species because of insufficient statistical power. In contrast to the prey species, L. bohar should be directly affected by fishing rather than through changes in predation rates or predation risk. The evidence that $L$. bohar is more abundant and attains a larger size and age in Palmyra as compared to those in fished north-western Kiritimati is consistent with this hypothesis (Ruttenberg et al., 2011). The lower abundance of L. bohar in north-western Kiritimati may, however, be expected to be associated with lower interspecific resource competition and higher body condition, if resources are limiting (Lizaso et al., 2000). Unfortunately, there are no data on resource consumption for any of the species in this study.

The pattern of high prey body mass on reefs with high fishing and low predator abundance was corroborated by patterns in liver mass. The liver is an important area for energy storage and is usually the first site for lipid storage, especially in non-fatty fishes (Cowey \& Sargent, 1977; Chellappa et al., 1995; Pratchett et al., 2004). These data suggest that prey fishes at reefs with high fishing intensity are not just heavier at a given length, but have more of their mass stored in the liver (note that liver mass was compared by controlling for total body mass). Body condition, measured by body mass and liver mass, represents the integrated energetic history of the fish (Gagliano \& McCormick, 2004). The liver is, however, sensitive to short-term variation in a fish's energy balance and is affected by reproductive events (Pratchett et al., 2004). For example, liver mass may vary with short-term changes in food availability and energy expenditure and it may also decrease during spawning (Eliassen \& Vahl, 1982; Black \& Love, 1986; Lambert \& Dutil, 1997; Green \& McCornick, 1999; Morgan et al., 2010). Stochastic or unsynchronized changes in these factors across reefs may have obscured the effect of predator abundance (and potential predation and predation risk) on energy reserves and may explain the inconsistent pattern in prey-fish liver mass among species. In addition, liver mass is not necessarily the best indicator of energy reserves in A. nigricans because fishes of this genus store fat in mesenteries surrounding the gut and the visceral cavity (Fichelson et al., 1985), which may explain the lack of difference in liver mass across all reefs for A. nigricans. Anecdotal observations made during dissections, however, revealed that fat deposits were more common in fishes from fished north-western Kiritimati, where 
body mass was greater, than from lightly fished south-eastern Kiritimati and unfished Palmyra, which supports the hypothesis of higher energy reserves in locations where predators are less abundant.

Adult body mass and energy reserves should have important consequences for reproduction, yet, consistent effects have been difficult to predict and observe (Stearns, 1992; Peckarsky et al., 1993; Scrimgeour and Culp, 1994; Boonstra et al., 1998). Only one prey fish of the three examined showed significant differences in adjusted mean gonad mass across reefs. In Palmyra, where predator abundance is high, A. nigricans was in poor body condition, but exhibited elevated reproductive potential relative to south-eastern Kiritimati and north-western Kiritimati. The pattern in body mass and gonad mass suggests that there may be a trade-off in condition and reproductive potential for A. nigricans. Other studies have shown that these trade-offs may occur when food resources are limiting (Levins, 1968; Sibley \& Calow, 1986; Stearns, 1992; Karels et al., 2000). While no direct information about food resources is available, food may be more limiting in Palmyra for A. nigricans because of reduced foraging areas (Madin et al., 2010). Plectroglyphidodon dickii and C. margaritifer, however, showed no differences in gonad mass despite also having reduced foraging areas in Palmyra (Madin et al., 2010). A variety of factors may have influenced reproductive potential in these prey fishes (e.g. differences in food availability or energy intake and changes in reproductive timing), but unfortunately these factors cannot be evaluated in this study. Alternatively, differences in reproductive potential using gonad mass may not have been detected because this is a coarse measure and little is known of the variability in the developmental schedule of the gonads of these species in the Line Islands.

It is also possible that differences in resource competition or environmental conditions across the study sites could explain the observed patterns. Higher prey abundance may result in high resource competition and low body condition, if resources are limiting (Lizaso et al., 2000). Previous studies, however, found no consistent pattern in the biomass of the major prey trophic groups (benthic invertivores, herbivores, omnivores and planktivores) that the study species represent (DeMartini et al., 2008; Sandin et al., 2008; Walsh, 2011). Even if fishing predators did lead to a higher abundance of prey, this mechanism would predict that prey may have lower body condition on fished reefs with low predator abundance, if resource abundance is similar, which is the opposite pattern in condition to what was observed. In addition, the consistently lower body condition found across prey species from different trophic groups on reefs with low fishing and high predator abundance suggests that the effect of predator abundance may be more important than the effect of any differences in abundance or availability of resources.

The small environmental differences among sites suggest that these factors are not wholly responsible for the observed patterns either. Kiritimati and Palmyra are relatively close together and have similar reef structures and oceanographic conditions (Sandin et al., 2008). Other studies have reported differences in individual traits due to spatial variation in environmental conditions that typically span large spatial and environmental gradients (Schultz \& Conover, 1997; Meekan et al., 2001; Choat \& Robertson, 2002; Robertson et al., 2005; Ruttenberg et al., 2005). In contrast, the differences in temperature $\left(2^{\circ} \mathrm{C}\right)$ and productivity $\left(0.07 \mathrm{mg} \mathrm{m}^{-3}\right.$ chlorophyll $\left.a\right)$ between Palmyra and Kiritimati are relatively small and may be biologically trivial compared to the magnitude of the difference in predator abundance among atolls (five 
to seven-fold) (Table I). Importantly, differences in prey body mass were observed both within the island of Kiritimati and across the islands of Kiritimati and Palmyra. This suggests that differences in predator abundance within and across islands were more important than differences in environmental conditions across islands.

This study provides some of the first evidence of the indirect effects of fishing on proxies of condition and reproduction across multiple trophic levels of coral-reef fishes inhabiting predator-dominated and fished coral reefs. Fishing predators may have indirectly resulted in increased condition of prey species, but the effects on prey reproductive potential were less clear and may have been mediated by other factors. Heithaus et al. (2008) predicts that effects of predation risk should be more important than direct effects of predation in more complex habitats with longer lived prey species; however, this study was unable to separate the effects of predation and predation risk. Together with related studies on the effects of fishing predators in the northern Line Islands, it provides important information to help account for both the direct and indirect effects of fishing in the context of management and conservation (Stallings, 2008). A number of observational studies have documented changes in individual traits in target fishery species and related them to changes in fisheries productivity (Rijnsdorp, 1993; Lambert \& Dutil, 1997; Conover \& Munch, 2002; Olsen et al., 2004). Understanding, however, how fishing indirectly affects these traits in communities of non-target species, the consequences for nontarget species populations and feedbacks to fisheries productivity are important next steps for ecosystem-based fisheries management (National Research Council, 2006; Heithaus et al., 2008; Stallings, 2008).

We would like to thank the Kiribati Ministry of Fisheries for permitting this research and assistance in the field. Oceanographic data used in this study were produced with the Giovanni online data system, developed and maintained by the NASA GES DISC. This research was funded by an Ocean Conservancy/International Society for Reef Studies Fellowship and NSF Graduate Research Fellowship to S.M.W., a College of Creative Studies Summer Undergraduate Research Fellowship to M.K.D. and a private donation to S.A.S.

\section{SUPPORTING INFORMATION}

Supporting Information may be found in the online version of this paper:

TABLE SI. Comparison of candidate models for body mass. The dependent variable is total mass (log transformed). The predictor variables are the regions: south-eastern Kiritimati (KirSE) and Palmyra (Pal). The reference region is north-western Kiritimati (KirNW). All models are specified with standard length $\left(L_{\mathrm{s}}\right)$ as a covariate. Best fit models are in bold.

TABLE SII. Comparison of candidate models for liver mass. The dependent variable is liver mass (log transformed, except for Acanthurus nigricans). The predictor variables are the regions: south-eastern Kiritimati (KirSE) and Palmyra (Pal). The reference region is north-western Kiritimati (KirNW). All models are specified with total mass $\left(M_{\mathrm{T}}\right)$ as a covariate. Best fit models are in bold.

TABLE SIII. Comparison of candidate models for gonad mass. The dependent variable is gonad mass (log transformed). The predictor variables are the regions: 
south-eastern Kiritimati (KirSE) and Palmyra (Pal). The reference region is northwestern Kiritimati (KirNW). All models are specified with total mass $\left(M_{\mathrm{T}}\right)$ as a covariate. Best fit models are in bold.

Please note: Wiley-Blackwell are not responsible for the content or functionality of any supporting materials supplied by the authors. Any queries (other than missing material) should be directed to the corresponding author for the article.

\section{References}

Acker, J. G. \& Leptoukh, G. (2007). Online analysis enhances use of NASA earth science data. Eos Transactions American Geophysical Union 88, 14. doi: 10.1029/2007EO02 0003

Allen, G. R. (1986). Pomacentridae. In Smiths' Sea Fishes (Smith, M. M. \& Heemstra, P. C., eds), pp. 670-682. Berlin: Springer-Verlag.

Armsworth, P. R. (2001). Effects of fishing on a protogynous hermaphrodite. Canadian Journal of Fisheries and Aquatic Sciences 58, 568-578.

Ballón, M., Wosnitza-Mendo, C., Guevara-Carrasco, R. \& Bertrand, A. (2002). The impact of overfishing and El Niño on the condition factor and reproductive success of Peruvian hake, Merluccius gayi peruanus. Progress In Oceanography 79, 300-307.

Berumen, M. L., Pratt, M. W. \& McCormick, M. I. (2005). Within-reef differences in diet and body condition of coral-feeding butterflyfishes (Chaetodontidae). Marine Ecology Progress Series 287, 217-227.

Black, D. \& Love, R. M. (1986). The sequential mobilisation and restoration of energy reserves in tissues of Atlantic cod during starvation and refeeding. Journal of Comparative Physiology B 156, 469-479.

Boonstra, R., Hik, D., Singleton, G. R. \& Tinnikov, A. (1998). The impact of predatorinduced stress on the snowshoe hare cycle. Ecological Monographs 68, 371-394.

Borer, E. T., Seabloom, E. W., Shurin, J. B., Anderson, K. E., Blanchette, C. A., Broitman, B., Cooper, S. D. \& Halpern, B. S. (2005). What determines the strength of a trophic cascade? Ecology 86, 528-537.

Burnham, K. P. \& Anderson, D. R. (2002). Model Selection and Multimodel Inference: A Practical Information-theoretic Approach. New York, NY: Springer-Verlag.

Caddy, J. F. \& Rodhouse, P. G. (1998). Cephalopod and groundfish landings: evidence for ecological change in global fisheries? Reviews in Fish Biology and Fisheries 8, $431-444$.

Chellappa, S., Huntingford, F. A., Strang, R. H. C. \& Thomson, R. Y. (1995). Condition factor and hepatosomatic index as estimates of energy status in male three-spined stickleback. Journal of Fish Biology 47, 775-787.

Choat, J. H. \& Robertson, D. R. (2002). Age-based studies. In Coral Reef Fishes: Dynamics and Diversity in a Complex Ecosystem (Sale, P. F., ed.), pp. 57-80. San Diego, CA: Academic Press.

Choat, J. H., Robbins, W. D. \& Clements, K. D. (2004). The trophic status of herbivorous fishes on coral reefs. Marine Biology 145, 445-454.

Conover, D. O. \& Munch, S. B. (2002). Sustaining fisheries yields over evolutionary time scales. Science 297, 94-96.

Cowey, C. \& Sargent, J. (1977). Lipid nutrition in fish. Comparative Biochemistry and Physiology B 57, 269-273.

DeMartini, E. E., Friedlander, A. M. \& Holzwarth, S. R. (2005). Size at sex change in protogynous labroids, prey body size distributions, and apex predator densities at NW Hawaiian atolls. Marine Ecology Progress Series 297, 259-271.

DeMartini, E. E., Friedlander, A. M., Sandin, S. A. \& Sala, E. (2008). Differences in fishassemblage structure between fished and unfished atolls in the northern Line Islands, central Pacific. Marine Ecology Progress Series 365, 199-215.

Diehl, S. \& Eklöv, P. (1995). Effects of piscivore-mediated habitat use on resources, diet, and growth of perch. Ecology 76, 1712-1726. 
Dulvy, N. K., Polunin, N. V. C., Mill, A. C. \& Graham, N. A. J. (2004). Size structural change in lightly exploited coral reef fish communities: evidence for weak indirect effects. Canadian Journal of Fisheries and Aquatic Sciences 61, 466-475.

Eliassen, J.-E. \& Vahl, O. (1982). Seasonal variations in biochemical composition and energy content of liver, gonad and muscle of mature and immature cod, Gadus morhua (L.) from Balsfjorden, northern Norway. Journal of Fish Biology 20, 707-716.

Fichelson, L., Montgomery, W. L. \& Myrberg, A. A. (1985). A new fat body associated with the gonad of surgeonfishes (Acanthuridae: Teleostei). Marine Biology 86, 109-112.

Frimodt, C. (1995). Multilingual Illustrated Guide to the World's Commercial Warmwater Fish. Oxford: Fishing News Books.

Froese, R. (2006). Cube law, condition factor and weight-length relationships: history, metaanalysis and recommendations. Journal of Applied Ichthyology 22, 241-253. doi: 10.1111/j.1439-0426.2006.00805.x

Gagliano, M. \& McCormick, M. I. (2004). Feeding history influences otolith shape in tropical fish. Marine Ecology Progress Series 278, 291-296.

Garvey, J. E., Ostrand, K. G. \& Wahl, D. H. (2004). Energetics, predation, and ration affect size-dependent growth and mortality of fish during winter. Ecology 85, 2860-2871.

Godin, J. G. J. (1995). Predation risk and alternative mating tactics in male Trinidadian guppies (Poecilia reticulata). Oecologia 103, 224-229.

Goñi, R. (1998). Ecosystem effects of marine fisheries: an overview. Ocean and Coastal Management 40, 37-64.

Graham, N. A. J., Evans, R. D. \& Russ, G. R. (2003). The effects of marine reserve protection on the trophic relationships of reef fishes on the Great Barrier Reef. Environmental Conservation 30, 200-208.

Green, B. S. \& McCornick, M. I. (1999). Influence of larval feeding history on the body condition of Amphiprion melanopus. Journal of Fish Biology 55, 1273-1289.

Hamilton, S. L., Caselle, J. E., Standish, J. D., Schroeder, D. M., Milton, S. L., RosalesCasian, J. A. \& Sosa-Nishizaki, O. (2007). Size-selective harvesting alters life histories of a temperate sex-changing fish. Ecological Applications 17, 2268-2280.

Hamman, I. M., Boehlert, G. W. \& Wilson, C. D. (2004). Effects of steep topography on the flow and stratification near Palmyra Atoll. Ocean Dynamics 54, 460-473.

Hawkins, J. P. \& Roberts, C. M. (2003). Effects of fishing on sex-changing Caribbean parrotfishes. Biological Conservation 115, 213-226.

Hawlena, D. \& Schmitz, O. J. (2010). Herbivore physiological response to predation risk and implications for ecosystem nutrient dynamics. Proceedings of the National Academy of Sciences of the United States of America 107, 15503-15507.

Heithaus, M. R., Frid, A., Wirsing, A. J. \& Worm, B. (2008). Predicting ecological consequences of marine top predator declines. Trends in Ecology and Evolution 23, 202-210.

Hiatt, R. W. \& Strasburg, D. W. (1960). Ecological relationships of the fish fauna on coral reefs of the Marshall Islands. Ecological Monographs 30, 65-127.

Hik, D. S. (1995). Does risk of predation influence population dynamics? Evidence from cyclic decline of snowshoe hares. Wildlife Research 22, 115-129.

Hoey, A. S. \& McCormick, M. I. (2004). Selective predation for low body condition at the larval-juvenile transition of a coral reef fish. Oecologia 139, 23-29.

Holm, S. (1979). A simple sequentially rejective multiple test procedure. Scandinavian Journal of Statistics 6, 65-70.

Hurvich, C. M. \& Tsai, C.-L. (1989). Regression and time series model selection in small samples. Biometrika 76, 297-307.

Jackson, J. B. C., Kirby, M. X., Berger, W. H., Bjorndal, K. A., Botsford, L. W., Bourque, B. J., Bradbury, R. H., Cooke, R., Erlandson, J., Estes, J. A., Hughes, T. P., Kidwell, S., Lange, C. B., Lenihan, H. S., Pandolfi, J. M., Peterson, C. H., Steneck, R. S., Tegner, M. J. \& Warner, R. R. (2001). Historical overfishing and the recent collapse of coastal ecosystems. Science 293, 629-638.

Jones, E. \& Dornhaus, A. (2011). Predation risk makes bees reject rewarding flowers and reduce foraging activity. Behavioral Ecology and Sociobiology 65, 1-7.

Karels, T. J., Byrom, A. E., Boonstra, R. \& Krebs, C. J. (2000). The interactive effects of food and predators on reproduction and overwinter survival of Arctic ground squirrels. Journal of Animal Ecology 69, 235-247. 
Kiribati Statistics Office (2005). Population Census. Bairiki: Government of the Republic of Kiribati.

Knowlton, N. \& Jackson, J. B. C. (2008). Shifting baselines, local impacts, and global change on coral reefs. PLoS Biology 6, e54.

Kotiaho, J., Alatalo, R. V., Mappes, J., Parri, S. \& Rivero, A. (1998). Male mating success and risk of predation in a wolf spider: a balance between sexual and natural selection? Journal of Animal Ecology 67, 287-291.

Lambert, Y. \& Dutil, J.-D. (1997). Condition and energy reserves of Atlantic cod (Gadus morhua) during the collapse of the northern Gulf of St. Lawrence stock. Canadian Journal of Fisheries and Aquatic Sciences 54, 2388-2400.

Lambert, Y. \& Dutil, J.-D. (2000). Energetic consequences of reproduction in Atlantic cod (Gadus morhua) in relation to spawning level of somatic energy reserves. Canadian Journal of Fisheries and Aquatic Sciences 57, 815-825.

Levins, R. (1968). Evolution in Changing Environments. Princeton, NJ: Princeton University Press.

Lieske, E. \& Myers, R. (1994). Collins Pocket Guide: Coral Reef Fishes. New York, NY: Harper Collins.

Lima, S. L. (1986). Predation risk and unpredictable feeding conditions: determinants of body mass in birds. Ecology 67, 377-385.

Lima, S. L. (1998). Nonlethal effects in the ecology of predator-prey interactions. BioScience 48, 25-34.

Lizaso, J. L. S., Goni, R., Renones, O., Charton, J. A. G., Galzin, R., Bayle, J. T., Jerez, P. S., Ruzafa, A. P. \& Ramos, A. A. (2000). Density dependence in marine protected populations: a review. Environmental Conservation 27, 144-158.

Lloret, J. \& Planes, S. (2003). Condition, feeding and reproductive potential of white seabream Diplodus sargus as indicators of habitat quality and the effect of reserve protection in the northwestern Mediterranean. Marine Ecology Progress Series 248, 197-208.

Longland, W. S. (1991). Risk of predation and food consumption by black-tailed jackrabbits. Journal of Range Management 44, 447-450.

Madin, E. M. P., Gaines, S. D. \& Warner, R. R. (2010). Field evidence for pervasive indirect effects of fishing on prey foraging behavior. Ecology 91, 3563-3571.

McClanahan, T. R. \& Muthiga, N. A. (1988). Changes in Kenyan coral-reef community structure and function due to exploitation. Hydrobiologia 166, 269-276.

McCormick, M. I. \& Molony, B. W. (1995). Influence of water temperature during the larval stage on size, age and body condition of tropical reef fish at settlement. Marine Ecology Progress Series 118, 59-68.

Meekan, M. G., Ackerman, J. L. \& Wellington, G. M. (2001). Demography and age structure of coral reef damselfishes in the tropical eastern Pacific Ocean. Marine Ecology Progress Series 212, 223-232.

Montgomery, W. L. \& Galzin, R. (1993). Seasonality in gonads, fat deposits and condition of tropical surgeonfishes (Teleostei: Acanthuridae). Marine Biology 115, 529-536.

Morgan, M. J., Rideout, R. M. \& Colbourne, E. B. (2010). Impact of environmental temperature on Atlantic cod Gadus morhua energy allocation to growth, condition and reproduction. Marine Ecology Progress Series 404, 185-195.

Morrison, L. W. (1999). Indirect effects of phorid fly parasitoids on the mechanisms of interspecific competition among ants. Oecologia 121, 113-122.

Myers, R. F. (1991). Micronesian Reef Fishes: A Practical guide to the Identification of the Coral Reef Fishes of the Tropical Central and Western Pacific. Barrigada: Coral Graphics.

Myers, R. F. (1999). Micronesian Reef Fishes: A Comprehensive Guide to the Coral Reef Fishes of Micronesia, 3rd edn. Barrigada: Coral Graphics.

Myers, R. A. \& Worm, B. (2003). Rapid worldwide depletion of predatory fish communities. Nature 423, 280-283.

Myers, R. A., Baum, J. K., Shepherd, T. D., Powers, S. P. \& Peterson, C. H. (2007). Cascading effects of the loss of apex predatory sharks from a coastal ocean. Science 315, $1846-1850$. 
Newman, M. J. H., Paredes, G. A., Sala, E. \& Jackson, J. B. C. (2006). Structure of Caribbean coral reef communities across a large gradient of fish biomass. Ecology Letters 9, $1216-1227$.

Olsen, E. M., Heino, M., Lilly, G. R., Morgan, M. J., Brattey, J., Ernande, B. \& Dieckmann, U. (2004). Maturation trends indicative of rapid evolution preceded the collapse of northern cod. Nature 428, 932-935.

Pandolfi, J. M., Bradbury, R. H., Sala, E., Hughes, T. P., Bjorndal, K. A., Cooke, R. G., McArdle, D., McClenachan, L., Newman, M. J. H., Paredes, G., Warner, R. R. \& Jackson, J. B. C. (2003). Global trajectories of the long-term decline of coral reef ecosystems. Science 301, 955-958.

Peckarsky, B. L., Cowan, C. A., Penton, M. A. \& Anderson, C. (1993). Sublethal consequences of stream-dwelling predatory stoneflies on mayfly growth and fecundity. Ecology 74, 1836-1846.

Pérez-Tris, J., Díaz, J. A. \& Tellería, J. L. (2004). Loss of body mass under predation risk: cost of antipredatory behaviour or adaptive fit-for-escape? Animal Behaviour 67, 511-521.

Pratchett, M. S., Wilson, S. K., Berumen, M. L. \& McCormick, M. I. (2004). Sublethal effects of coral bleaching on an obligate coral feeding butterflyfish. Coral Reefs 23, $352-356$.

Randall, J. E. \& Brock, V. E. (1960). Observations on the ecology of epinepheline and lutjanid fishes of the Society Islands, with emphasis on food habits. Transactions of the American Fisheries Society 89, 9-16.

Randall, J. E., Allen, G. R. \& Steene, R. C. (1990). Fishes of the Great Barrier Reef and Coral Sea. Honolulu, HI: University of Hawaii Press.

Reznick, D. \& Endler, J. A. (1982). The impact of predation on life history evolution in Trinidadian guppies (Poecilia reticulata). Evolution 36, 160-177.

Rijnsdorp, A. (1993). Fisheries as a large-scale experiment on life-history evolution: disentangling phenotypic and genetic effects in changes in maturation and reproduction of North Sea plaice, Pleuronectes platessa L. Oecologia 96, 391-401.

Rijnsdorp, A. D., van Damme, C. J. G. \& Witthames, P. R. (2010). Implications of fisheriesinduced changes in stock structure and reproductive potential for stock recovery of a sex-dimorphic species, North Sea plaice. ICES Journal of Marine Science: Journal du Conseil 67, 1931-1938.

Robertson, D. R., Ackerman, J. L., Choat, J. H., Posada, J. M. \& Pitt, J. (2005). Ocean surgeonfish Acanthurus bahianus. I. The geography of demography. Marine Ecology Progress Series 295, 229-244.

Ruttenberg, B., Haupt, A., Chiriboga, A. \& Warner, R. (2005). Patterns, causes and consequences of regional variation in the ecology and life history of a reef fish. Oecologia 145, 394-403.

Ruttenberg, B., Hamilton, S. L., Walsh, S. M., Donovan, M. K., Friedlander, A., DeMartini, E., Sala, E. \& Sandin, S. A. (2011). Predator-induced demographic shifts in coral reef fish assemblages. PLoS One 6, e21062. doi: 10.1371/journal.pone.0021062

Sandin, S. A., Smith, J. E., DeMartini, E. E., Dinsdale, E. A., Donner, S. D., Friedlander, A. M., Konotchick, T., Malay, M., Maragos, J. E., Obura, D., Pantos, O., Paulay, G., Richie, M., Rohwer, F., Schroeder, R. E., Walsh, S., Jackson, J. B. C., Knowlton, N. $\&$ Sala, E. (2008). Baselines and degradation of coral reefs in the northern Line Islands. PLoS One 3, e1548.

Sandin, S. A., Walsh, S. M. \& Jackson, J. B. C. (2010). Prey release, trophic cascades, and phase shifts in tropical nearshore ecosystems. In Trophic Cascades: Predators, Prey, and the Changing Dynamics of Nature (Terborgh, J. \& Estes, J. A., eds.), pp. 71-90. Washington, DC: Island Press.

Schmitz, O. J., Beckerman, A. P. \& O’Brien, K. M. (1997). Behaviorally mediated trophic cascades: effects of predation risk on food web interactions. Ecology 78, 1388-1399.

Schultz, E. T. \& Conover, D. O. (1997). Latitudinal differences in somatic energy storage: adaptive responses to seasonality in an estuarine fish (Atherinidae: Menidia menidia). Oecologia 109, 516-529.

Scrimgeour, G. J. \& Culp, J. M. (1994). Feeding while evading predators by a lotic mayfly: linking short-term foraging behaviours to long-term fitness consequences. Oecologia 100, $128-134$. 
Sibley, R. M. \& Calow, P. (1986). Physiological Ecology of Animals: An Evolutionary Approach. Oxford: Blackwell Scientific Publications.

Sih, A. (1980). Optimal behavior: can foragers balance two conflicting demands? Science 210, 1041-1043.

Skelly, D. K. \& Werner, E. E. (1990). Behavioral and life-historical responses of larval American toads to an odonate predator. Ecology 71, 2313-2322.

Slos, S. \& Stoks, R. (2008). Predation risk induces stress proteins and reduces antioxidant defense. Functional Ecology 22, 637-642.

Stallings, C. D. (2008). Indirect effects of an exploited predator on recruitment of coral-reef fishes. Ecology 89, 2090-2095.

Stearns, S. C. (1992). The Evolution of Life Histories. Oxford: Oxford University Press.

Stevenson, C., Katz, L. S., Micheli, F., Block, B., Heiman, K. W., Perle, C., Weng, K., Dunbar, R. \& Witting, J. (2007). High apex predator biomass on remote Pacific islands. Coral Reefs 26, 47-51.

Sunardi, Asaeda, T. \& Manatunge, J. (2007). Physiological responses of topmouth gudgeon, Pseudorasbora parva, to predator cues and variation of current velocity. Aquatic Ecology 41, 111-118.

Terborgh, J. \& Estes, J. A. (Eds) (2010). Trophic Cascades: Predators, Prey, and the Changing Dynamics of Nature. Washington, DC: Island Press.

Walsh, S. M. (2011). Ecosystem-scale effects of nutrients and fishing on coral reefs. Journal of Marine Biology (in press). doi: 10.1155/2011/187248

Werner, E. E., Gilliam, J. F., Hall, D. J. \& Mittelbach, G. G. (1983). An experimental test of the effects of predation risk on habitat use in fish. Ecology 64, 1540-1548.

Wingfield, J. C., Maney, D. L., Bruener, C. W., Jacobs, J. D., Lynn, S., Ramenofsky, M. \& Richardson, R. D. (1998). Ecological bases of hormone-behavior interactions; the "emergency life history stage". American Zoologist 38, 191-206.

Woodley, C. M. \& Peterson, M. S. (2003). Measuring responses to simulated predation threat using behavioral and physiological metrics: the role of aquatic vegetation. Oecologia 136, $155-160$.

\section{Electronic References}

Dayton, P. K., Thrush, S. \& Coleman, F. C. (2002). Ecological Effects of Fishing in Marine Ecosystems of the United States. Available at http://www.pewtrusts.org/uploadedFiles/ wwwpewtrustsorg/Reports/protecting_ocean_life/environment_pew_oceans_effects_ fishing.pdf/

Federal Register (2001). Establishment of the Palmyra Atoll National Wildlife Refuge. Available at http://www.gpo.gov/fdsys/search/home.action/

Kempthorne, D. (2009). Delegation of Management Responsibility for the Pacific Remote Islands Marine National Monument. Order number 3284. Available at http://elips.doi. gov/app_so/act_getfiles.cfm?order_number $=3284$ /

National Research Council (2006). Dynamic Changes in Marine Ecosystems: Fishing, Food Webs, and Future Options. Available at http://www.nap.edu/catalog.php?record_id= $11608 /$ 